\title{
Railroads and Reform: How Trains Strengthened the Nation State
}

\author{
Alexandra L. Cermeño ${ }^{1}$ (D) Kerstin Enflo $^{1}$ (D) and Johannes Lindvall ${ }^{2 *}$ (D) \\ ${ }^{1}$ Department of Economic History, Lund University, Lund, Sweden and ${ }^{2}$ Department of Political Science, Lund University, \\ Lund, Sweden \\ *Corresponding author. E-mail: johannes.lindvall@svet.lu.se
}

(Received 14 January 2020; revised 26 June 2020; accepted 11 September 2020; first published online 5 April 2021)

\begin{abstract}
This paper examines the relationship between the coming of the railroads, the expansion of primary education, and the introduction of national school curricula. Using fine-grained data on local education outcomes in Sweden in the nineteenth century, the paper tests the idea that the development of the railroad network enabled national school inspectors to monitor remote schools more effectively. In localities to which school inspectors could travel by rail, a larger share of children attended permanent public schools and took classes in nation-building subjects such as geography and history. By contrast, the parochial interests of local and religious authorities continued to dominate in remote areas school inspectors could not reach by train. The paper argues for a causal interpretation of these findings, which are robust for the share of children in permanent schools and suggestive for the content of the curriculum. The paper therefore concludes that the railroad, the defining innovation of the First Industrial Revolution, mattered directly for the state's ability to implement public policies.
\end{abstract}

Key words: railroads; education; state capacity; Sweden

Do technological advances increase state capacity? Throughout history, new technologies such as the printing press, the telegraph, and the automobile have transformed cultures, societies, and economies. But do new technologies also transform the state itself? This paper argues that the answer is yes, since new technologies often allow governments to do things they could not previously do, strengthening the state vis-à-vis other institutions, organizations, and interest groups. On the basis of a novel argument about the relationship between technology and state capacity and using detailed data from Sweden, we present an empirical analysis of how the main technological innovation of the First Industrial Revolution, the railroad, influenced one of the nineteenth century's defining social institutions, primary schooling, by empowering national school inspectors.

Historians, political scientists, sociologists, and economists have long taken for granted that the coming of the railroads had important cultural, social, and economic effects in the nineteenth-century world. But there are remarkably few empirical studies of the direct effect of the railroads on the state, and, more specifically, on how public officials carried out their duties (indeed, there are remarkably few empirical studies of the relationship between any technological innovations and the development of state capacity). For example, Eugen Weber's Peasants into Frenchmen (1976), a major source of inspiration for our work, has a lot to say about both the French railroads and the French school inspectorate, but it says little about the effect of one on the other; in other words, it does not show whether the availability of rail transport made school inspectors more effective.

(c) The Author(s), 2021. Published by Cambridge University Press. This is an Open Access article, distributed under the terms of the Creative Commons Attribution licence (http://creativecommons.org/licenses/by/4.0/), which permits unrestricted re-use, distribution, and reproduction in any medium, provided the original work is properly cited. 
We combine fine-grained data on the provision of primary education in different localities in Sweden in 1868 with geographic-information-system data on the location of each train station and the home address of each Swedish school inspector in that year. This research design allows us to study the association between railroads and state capacity: the ability of state officials to enforce and implement government policies. Controlling for many important confounders and relying on data that allow us to describe the travel options of each school inspector with great precision, we argue for a causal interpretation of our findings.

The evidence we present suggests that the development of the Swedish railroad network enabled school inspectors to monitor schools more effectively, strengthening the implementation of national school policies. National and local authorities disagreed over the provision of public education since the national government wanted local authorities to pay for permanent public schools whereas local authorities preferred less expensive ambulatory schools. They also disagreed over the content of the curriculum, for nineteenth-century national-local conflicts were also state-church conflicts: in Sweden, the modernizing nation state sought to mold children into loyal citizens by teaching them subjects such as geography and history, but local priests mainly wanted children to learn the Lutheran catechism. We show that if a school inspector could get to remote schools by train, the proportion of permanent schools in a school district was considerably higher than if the school inspector depended on other means of transportation. The proportion of geography and history in the curriculum was also higher where remote schools could be reached by train. We are less confident in the causal interpretation of this finding than the finding regarding permanent schools, but our results are at least suggestive that the railroad also had an effect on what was taught in the schools.

In addition to its indirect effects via cultural and socioeconomic modernization, we thus argue that the railroads had direct, positive effects on the capacity of the central state. This argument has important implications for theories of state capacity, education, and comparative political development.

\section{Trains, States, and Schools}

Scholars have long believed that modern technology transformed politics in the nineteenth and twentieth centuries. The political scientist Samuel Finer wrote in his magnum opus The History of Government (1997, Book III, 1610-1618) that the development of the modern state in the nineteenth century was only possible because of technological changes associated with the Industrial Revolution. The sociologist Michael Mann observed in his magnum opus, The Sources of Social Power (1993), that the increase in the state's 'infrastructural power' in the nineteenth and twentieth centuries was a consequence of new technologies that allowed the state to penetrate civil society, including new modes of transport and new administrative practices that were made possible by modern communications and high levels of literacy. Long before that, the economist John Hicks noted in his Theory of Economic History (1969) that new technologies have had profound effects on public administration: 'Modern governments, one would guess, overuse the aeroplane,' Hicks wrote, 'but where would they be without the telephone - and the typewriter?' (Hicks 1969, 99).

But empirical studies of the relationship between technology and political development are few and far between. The studies that do exist typically treat the effects of technology as indirect operating through cultural and socioeconomic modernization - and not as direct effects on the state itself (see, for example, Schram (1997) on railroads in Italy and Clark (1998) on railroads in Ecuador). What interests us here is whether and how a new technology, the railroad, increased state capacity: the 'institutional capability of the state to carry out various policies' (Besley and Persson 2011,6) and the 'degree of control that state agents exercise over persons, activities, and resources within their government's territorial jurisdiction' (McAdam, Tarrow, and Tilly 2001, 78). 
When it comes to the relationship between technology and state capacity, the specific mechanism we are interested in is that the railroad improved the ability of the school inspectors to monitor local schools in remote areas. Before the introduction of modern forms of transportation (notably the railroad) and modern forms of communication (such as the telegraph), both longdistance travel and the long-distance exchange of messages were very time-consuming. It was therefore difficult for state agents to establish effective control and implement national policies throughout the state's territory. As Soifer (2015) shows in his recent book on state building in Latin America, the implementation of national policies has historically been more effective where bureaucrats were sent out by, and responsive to, the central government - as opposed to being appointed by, and responsive to, local elites. Before the introduction of modern forms of transportation and communication, this form of centralization was often not possible at all.

We concentrate on education for two reasons. First of all, the creation of national education systems was an exceptionally important event, which transformed the relationship between states and citizens and which had many other cultural and economic effects besides (Aghion et al. 2019; Ansell and Lindvall 2013, Ansell and Lindvall 2021; Benavot et al. 1991; Benavot and Riddle 1988; Lindert 2004; Meyer, Ramirez, and Soysal 1992; Soysal and Strang 1989). Second, the expansion of primary education led to one of the nineteenth century's defining political conflicts: the struggle between the 'centralizing, standardizing, and mobilizing Nation-State' and the 'historically established corporate privileges of the Church' (Lipset, Martin, and Rokkan 1967, 14-15, emphasis in original). As Lipset and Rokkan note, 'the fundamental issue between church and state was the control of education.'

The struggle over the control of education was a church-state conflict and a local-national conflict at the same time. The 'school wars' of nineteenth- and early-twentieth-century Europe involved both the question of secularization (whether the responsibility for primary education should be shifted from religious institutions such as parishes and dioceses to secular bureaucracies) and the question of centralization (whether schools should be administered by local or regional authorities, or by the central government). The famous French school reforms of the 1880s, the 'Ferry Laws,' are a particularly clear example. When France's Republican reformers introduced new legislation that made education secular - deepening the conflict between the French state and the Catholic Church that ended with the adoption of the Law of 9 December 1905 concerning the Separation of the Churches and the State - they also made the central government financially and administratively responsible for primary education.

It is a curious fact that these sorts of conflicts only began in earnest in the second half of the nineteenth century (Ansell and Lindvall 2013), even if the latent conflict between modernizing elites in national capitals and conservative and religious authorities in the periphery existed well before that time. In our view, the best explanation for the increasing salience of localnational conflicts and church-state conflicts in the second half of the nineteenth century is that before the construction of the railroads, national governments were simply unable to establish the sort of direct control that is required to run something as complicated as a school system. In other words, without modern technology, states would not have been able to centralize, or even secularize, primary education.

The ideas and findings we report in this paper are mainly concerned with the ability of the state, or agents of the state, to monitor the implementation of public policies by local-level decision makers. They are likely to be generalizable to other situations in which governments seek to monitor local authorities. There are many such examples, both historically and in the contemporary world. For example, already in the nineteenth century, many governments appointed health

\footnotetext{
${ }^{1}$ It is also important to keep in mind the role that education was expected to play in the development of national defense capabilities (Aghion et al. 2019) - a connection that is especially relevant in the context of this paper, since investments both in the railroad and in the school system were promoted by nineteenth-century reformers in the interest of strengthening the military.
} 
and public-health inspectors that oversaw the implementation of national policies concerning, for example, vaccinations (cf. Ansell and Lindvall 2021, Part IV). The paper's ideas and findings are also generalizable to situations in which national governments seek to monitor private organizations that carry out public functions. An important nineteenth-century example here is mentalhealth institutions. In nineteenth-century England, for instance, the national 'Commissioners of Lunacy' inspected both local, county, and private mental institutions (Jones 1972).

In policy areas where state capacity does not primarily rely on the ability of state agents to monitor other institutions and organizations, transportation technologies such as the railroad - or indeed the automobile - are not likely to matter as much. But other technologies may matter more. The effects of internet-based technologies on state capacity today, for instance, are not primarily a result of the state's ability to monitor other decision makers - at least in liberal, democratic states, what matters is the ability of citizens to interact with the state, as in countries where citizens can claim government benefits through web-based interfaces. This paper's general arguments about the crucial relationship between technology and state capacity are therefore likely to have broad application.

Our study is related to other recent studies that have examined the political effects of transportation technologies and networks. For example, Nall (2018) has recently described the relationship between the development of the Interstate Highway System in the United States during the 1940s to the subsequent evolution of American politics. In his book, Nall argues that the highways reshaped the American political landscape by aiding the movement of the white middle- and upper-middle classes to the suburbs. The resulting spatial sorting of households also affected subsequent local public transportation policies. In a similar vein, Baum-Snow (2007) has studied the relationship between the Interstate Highway System and urbanization. His analysis shows that the main cities in metropolitan areas declined by 17 per cent on average, despite an aggregate population growth of 72 per cent, which suggests that the population shifted to suburban areas, as described by Nall. These changes in political geography also mattered for the education system due to increased school segregation. Baum-Snow and Lutz (2011) suggest that a decline of 6 to 12 per cent in white public school enrollment, due to the desegregation policy, manifested primarily as an effect of suburban migration, and infer that part of the effect was also related to an increase in private schooling. We share, with these studies, an interest in the role of transportation technology, but our framework emphasizes the struggle between national political authorities and recalcitrant local and religious communities, not the economic and political responses of individual citizens to changes in transportation. We concentrate on how the prospect of being monitored by state officials affects local resistance to top-down political change.

\section{Swedish Schools in the 1860s}

Sweden's nationwide compulsory public school system was established in 1842, when the Swedish parliament, the Diet of the Estates, adopted the Education Ordinance, folkskolestadgan. Under the Education Ordinance, primary schools were funded and administered by local governments, which were, at the time, coextensive with the parishes of the Lutheran state church.

The school system that was established under the Education Ordinance contained two conflicts of interest between national and local authorities. First of all, there was a conflict of interest over the provision of primary education per se. $₫ 1$ of the Education Ordinance provided that each parish must have at least one school, preferably a permanent school that employed a skilled teacher. But $\$ 2$ of the Education Ordinance provided that at least for some time, parishes could opt to operate ambulatory schools instead of establishing permanent schools with their own purpose-built buildings. Parents were often reluctant to release their children from what they saw as more important work around the home, and local tax payers were often reluctant to pay for teachers and school buildings. Where resources were thin and resistance was great, 
local authorities therefore often preferred to set up ambulatory schools, as a cheaper, temporary alternative to constructing permanent school buildings and employing teachers on regular contracts.

Second, there was a conflict of interest over the content of the curriculum. $\$ 6$ of the Education Ordinance provided that all teachers must be able to teach the Catechism of the Lutheran church, biblical history, natural and political geography, history, arithmetic, geometry, and natural sciences. In addition, writing, drawing, physical education, and singing were taught in the schools. ${ }^{2}$ But $\$ 7$ provided that children did not have to pass exams in all these subjects; they were allowed to graduate if they had enough knowledge in the Swedish language, sufficient knowledge of biblical history and the Catechism to be confirmed in the Lutheran church, and adequate skills in arithmetic, writing, and - except in truly hopeless cases - singing. Again, the provisions of the Education Ordinance made it possible for local decision-makers to avoid implementing some of the national government's more ambitious policies.

In 1861, parliament decided to appoint national school inspectors to promote the implementation of the provisions of the Education Ordinance throughout the country. In particular, the school inspectorate was meant to contribute to a greater expansion of permanent public schools (Nilsson 2018, 11), but they were also committed to increasing the number of children who learned geography and history, which were seen as subjects that were essential to a modern, 'citizen-oriented' education system (Evertsson 2012, 639). Before 1861, schools were inspected by local authorities that sorted under the parishes themselves; starting in 1861, the state sought to increase its control over local schools. As Thelin (1994) notes, the inspectors were meant to be the 'government's eyes in the parishes.' They were selected from the region in which the inspected school districts were located - the bishops submitted recommendations to the Ministry of Education in Stockholm - but the final appointment decisions were made in the capital. The idea was to appoint individuals whose reputation would ensure that the inspections were not met with 'a contemptuous grin' among local decision-makers and teachers (Thelin 1994, 1415). The appointment of national school inspectors was an important step toward the centralization and secularization of the Swedish school system in the late nineteenth century and in the beginning of the twentieth (Tegborg 1969).

School inspectors were expected to visit local schools regularly, and each year submitted reports to the Ministry of Education. They promoted adherence to the Education Ordinance, inspected the school facilities, and advised teachers on how to improve their methods of teaching. From time to time, inspectors also taught their own classes. Moreover, starting in 1864, a few years before the specific period we examine, inspectors were expected to examine all students once per semester. Anecdotal evidence suggests that the school inspectors were widely feared: thinking back to his childhood in the late nineteenth century, the son of one station master with the railroads remembered that as soon as the school inspector had exited the train station, 'my father promptly ran to the telephone to warn the schools of his arrival' (Thelin 1994, 157).

When it comes to the two conflicts of interest we described above, the school inspectors typically promoted the policies of the national government. First of all, the inspectors fought the ambulatory schools energetically and pushed for the construction of permanent public schools (Ekholm and Lindvall 2008). Second, the school inspectors had a broader concept of learning than local decision-makers. Whereas local priests typically held the view that all children needed was enough knowledge of the Catechism and biblical history to be confirmed - or, in other words, that the basic knowledge and skills specified in $\$ 7$ of the Education Ordinance were enough - most school inspectors sought to convince local priests, school boards, and teachers to teach subjects that were associated with civil citizenship - particularly geography and history and not only religion (Evertsson 2012).

\footnotetext{
${ }^{2}$ History was referred to as the 'history of the homeland as well as the basics of general history' (fäderneslandets historia och hufvuddragen af allmänna historien); the emphasis was on the first part.
} 
In the period we are studying, the inspectors largely exercised 'soft power.' Only later, in the early twentieth century, were school inspectors granted more direct authority over local school policies. For example, from the 1914 school-inspectorate reform onward, they had a veto on the appointment of teachers (Jägerskiöld 1959, 82). In 1868, the year we study, the main instrument the inspectors had available was to name and shame school districts that performed badly in their annual reports and through other, more informal channels.

\section{Research Design and Data}

The argument behind our idea that trains strengthened the nation state is straightforward: where school inspectors were able to travel more easily, they were better able to enforce national policies. In Sweden, this meant pushing for children to attend permanent schools and to be taught subjects such as geography and history in addition to the Catechism. Before the arrival of the railroads, travel conditions were difficult. One historical study tells of a school inspector in 1862, Inspector Rudenschöld, who spent 262 days away from home, 'often on long journeys by horsedrawn carriage on lousy roads' (Nilsson 2018, 13, our translation).

To test the idea that the railroad made a big difference to the effectiveness of the inspectors, we conduct an empirical investigation of official data from 1868, a decade and a half after the parliament's 1854 decision to create a national railroad network and a few years after the 1861 decision to appoint national school inspectors for all school districts.

In 1868, Statistics Sweden compiled detailed data on schools and education outcomes in each of the 174 deaneries of the Swedish church (Statistiska Centralbyrån, 1870). The deanery, or kontrakt, is a level of church governance between the parish (the lowest level) and the diocese (the seat of a bishop). Our investigation is based on a cross-sectional comparison of 170 deaneries (for reasons that we explain below, we exclude four deaneries). We collect data from official sources on the share of children being educated in different types of schools and in different subjects in the year 1868. Unfortunately, data were not reported in this detailed form either before 1868 or after. Consequently, we only have access to a cross section of all deaneries in 1868 . The crosssectional research design permits a detailed econometric analysis of the correlates between the railroad expansion and education outcomes. We also argue, however, that the specific historical circumstances surrounding the gradual roll out of the railroad network, in combination with geography-specific controls, allows us to make causal claims on the basis of the estimated correlations. In the absence of detailed panel data, we are fortunate to have data from 1868, when the railroad network had not yet been extended to all the major towns and cities, which means that our main explanatory variable varies across all types of localities. Moreover, by 1868 , the national school inspectorate had only existed for a few years, which allows us to study the tension between national authorities and local, religious authorities at an early stage of this political struggle.

We concentrate on two types of data: the share of school-aged children in each locality attending permanent public schools (to test the effect of the railroads on the provision of education per se) and the number of children who received teaching in each subject (to test the effect of the railroads on the content of the curriculum).

Table 1 lists the share of students in all school forms in 1868 in the 170 deaneries in our study. As seen fom the table, public schools (folkskolor) were the most prominent school form. However, a significant share of children were in elementary schools ( 24 per cent) or home schooled (15 per cent). To be untaught was uncommon (only 2 per cent of all school-aged children did not attend school at all). Among the public schools, permanent schools were clearly preferred by the national government, and they were also more common ( 35 per cent) than the cheaper ambulatory schools (21 per cent).

When it comes to the relative importance of the different subjects that are listed in $\$ 6$ of the Education Ordinance, official statistics for the year 1868 report the number of children that were taught each subject. Unfortunately, we do not have information about how many hours the 
Table 1. Types of schooling in Sweden in 1868

\begin{tabular}{lr}
\hline School form & Per cent \\
\hline Public school (folkskola) & 55 \\
$\quad$ Permanent & 35 \\
$\quad$ Ambulatory & 21 \\
Elementary school & 24 \\
Home school & 15 \\
Other schoolact & 4 \\
Untaught & 2 \\
\hline
\end{tabular}

Source: Statistiska Centralbyrån (1870). Comments: The table provides information about the percentage of school students in each form of schooling in the average Swedish deanery in 1868. The deanery, a level of church governance between the parish and the diocese, is the unit of analysis in our study.

students were taught per subject; the inspectors only took note of the number of students that had, at some point during the semester, recived education in each of the subjects. Since the Cathechism was taught to virtually all students, we compare the number of students who received education in geography and history to the number of students that were taught the Catechism.

The railroad revolutionized overland travel in Sweden, as in other countries. On many routes, travel times were reduced up to ten times (Sjöberg 1956). Travelling between the two largest cities, Stockholm and Gothenburg, had previously taken several days, involving frequent stops and changing modes of transportation; the railroad made this journey possible to undertake in a single day.

In 1868, the Swedish railroad network was still in its infancy, which is why there is a great deal of cross-sectional variation in railroad connectivity that we can exploit in our analyses. Beginning in 1856, a first wave of state-sponsored trunk lines was built (Oredsson 1969). The original plan of the network consisted of five main trunk lines from north to south, connecting the entire country. Because of military concerns, however, and because of a desire to stimulate economic development in backward areas away from the prosperous coasts, the network was rerouted through the interior of the country, avoiding many important towns and transport hubs. This new plan did not impress the local representatives in the parliament, many of whom saw their home towns bypassed by the railroad lines and who regarded the plan's alleged 'fear of waterways and towns' as irrational (Heckscher 1954, 241). This political infighting delayed railroad development construction, especially since the business cycle turned downward in the late 1860s. Hence, by 1868 , Sweden had a network of railroads that connected the three largest population centers Stockholm, Gothenburg and Malmö - but many important parts of the country remained unconnected to the network. It was not until after the business cycle turned upward again during the 1870 s and 1880s that many of the proposed lines were built. The fact that some lines had been held up due to political infighting in the Riksdag is plausibly unrelated to relative differences in local growth and educational outcomes. As we explain below, we therefore think of deaneries with planned but yet unbuilt railroads as a reasonable placebo group that helps us see what school outcomes looked like absent the railroads.

Figure 1A describes the railroad network in the year 1868. Many of the areas through which the railroads were drawn were not particularly prosperous (darker colors represent high levels of gross domestic product per capita), and many cities remained unconnected. Berger and Enflo (2017, 128-129) show more formally that towns with and without rail by 1870 has equal access to domestic urban markets and a similar sectoral structure, measured by employment shares in artisanal, trade, military, manufacturing and service occupations prior to the construction to the network. Moreover, railroad towns did not exhibit any differences in their pre-rail urban growth patterns. Thus, it can be concluded that the early development of the Swedish railroad network was not a function of the prior level of economic development in different localities. Taken together, we argue that the low correlation between the railroad network and variables such as 


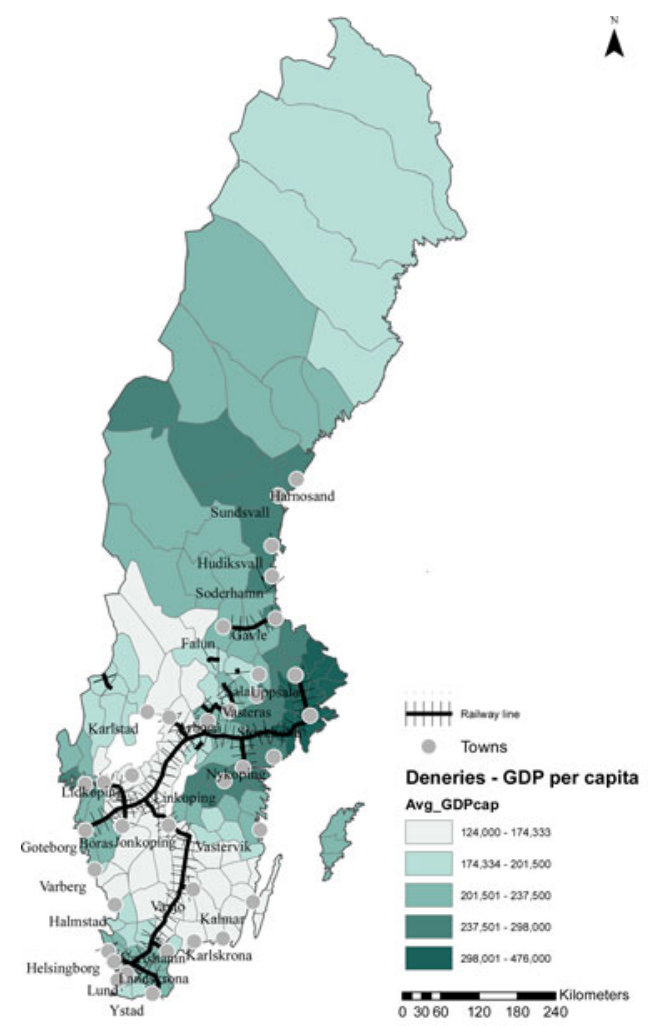

(A) Railroads, Towns, GDP

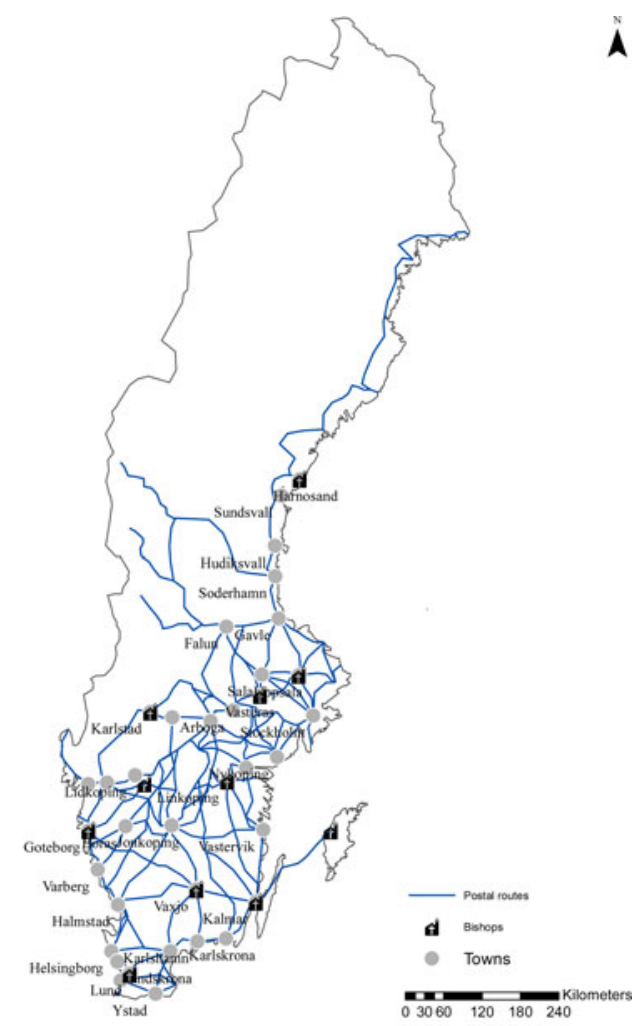

(B) Old Postal Routes

Figure 1. The railroad network and the old postal network.

GDP per capita and urbanisation, measured prior to the network, alleviate the obvious concern that any observed relationship between railroad access and education outcomes might be a result of underlying, pre-existing differences in prosperity, urbanization, or class structure.

But there are other potential confounders that are political, not economic: the railroads might have been routed through areas that were easier for planners to access due to pre-existing differences in local state capacity. As Dunlavy (1994) and others have shown, existing political structures typically shaped railroad development in the nineteenth century. We therefore need to consider the possibility that any observed correlation between the railroad network and education outcomes might reflect pre-existing political differences among localities. Measuring preindustrial local state capacity is not easy, but in the Swedish case, the early-modern state postal routes are a meaningful proxy. During Sweden's involvment in the Thirty Years' War, in the seventeenth century, the state's need for an efficient postal system became acute. The Postal Regulation of 1636 specified the obligations of the postal operators (who were in fact peasants living at an appropriate distance from each other). The postal routes were directed over land and water in summer and over snow and ice in the winter. The mail was supposed to be carried at all times of the day, and those who did not run the expected 10 kilometers an hour were condemned to eight days in prison on water and bread (Boije and Prenzlau-Enander 2003). Panel B in Fig. 1 compares the railroad network with the early-modern postal routes, which are digitized on the basis of a map from the middle of the eighteenth century. There were some areas - particularly in the north-western, mountainous part of the country - that still lacked both railroads and postal routes, but there were also many parts of the country that were included in the postal 
network but lacked railroads. This alleviates the concern that our rail variables might simply pick up pre-existing local variation in state capacity.

But the railroad network was clearly not entirely independent of previous economic and political structures, for the three main cities - Stockholm, Gothenburg, and Malmö - were, by design, the first to get a rail connection. We therefore drop the deaneries covering these three cities from our analysis, reducing the likelihood of biased results due to endogeneity. ${ }^{3} \mathrm{We}$ also include numerous control variables in our statistical analyses, as explained in the next section.

\section{Empirical Strategy}

We are interested in the effect of the railroad on the ability of state officials to implement public policies. The ideal experiment for testing this idea in the context of nineteenth-century school inspections in Sweden would have been to randomly assign railway connections - between school districts and inspectors' homes - among the deaneries that were remote from the homes of the inspectors, and then compare the school outcomes in remote deaneries to which school inspectors could and could not travel by train. Absent such experimental data, we instead rely on a historical case that has several compelling features, as we discussed in the previous section.

A first, rather naive approach to modelling the effect of the railroad would be to estimate the equation

$$
y_{i}=\alpha+\beta_{0} \operatorname{Railroad}_{i}+\gamma \mathbf{X}_{i}+\epsilon_{i}
$$

where $y_{i}$ is an outcome we wish to explain in deanery $i$ (that is, either the share of children in permanent schools or the proportion of children taking classes in geography and history), the variable Railroad takes the value 1 if there was a train station in deanery $i$ and 0 otherwise, and $\mathbf{X}$ is a vector of controls (which we discuss in more detail below).

But we can clearly improve on equation (1). First of all, if there was no train station near the inspector's home, the fact that there was a train station in the inspected deanery was of little help to the inspector. The first equation we actually estimate in the paper - first without and then with the controls included - is therefore equation (2), which replaces the variable Railroad with the variable (Railroad) Connection, which takes the value 1 if there was a train station in deanery $i$ and in the deanery where the inspector lived.

$$
y_{i}=\alpha+\beta_{1} \text { Connection }_{i}+\gamma \mathbf{X}_{i}+\epsilon_{i}
$$

The coefficient $\beta_{1}$; which is an estimate of the effect of railroad connectivity, is the main quantity of interest in our analyses.

We must also take into account that the railroad only mattered if the schools the inspector was tasked with inspecting were so remote that they were difficult to reach otherwise - by foot, on horseback, or using a horse-drawn carriage. To account for this, the next few models we estimate include the variable Within $30 \mathrm{~km}$, for school districts that were not remote, and then we interact that variable with the variable Connection.

$$
\begin{aligned}
y_{i}= & \alpha+\beta_{1} \text { Connection }_{i}+\beta_{2} \text { Within } 30 \mathrm{~km}_{i} \\
& +\beta_{3} \text { Connection }_{i} \times \text { Within } 30 \mathrm{~km}_{i}+\gamma \mathbf{X}_{i}+\boldsymbol{\epsilon}_{i}
\end{aligned}
$$

\footnotetext{
${ }^{3}$ In fact, the national school inspectors did not even inspect the schools in the two largest cities, Stockholm and Gothenburg. In the case of the capital, Stockholm, the city's school board arranged its own inspections, and reported directly to the government. In the case of Gothenburg, the school inspector responsible for the deaneries of Kind, Falkenberg, and Halmstad was formally responsible also for Gothenburg, but he did not carry out inspections, relying instead on reports that were prepared by city authorities. Due to a border change in the diocese of Linköping, we are also forced to drop the deanery of Lysing from our sample, which leaves us with the sample of 170 deaneries for the empirical analysis.
} 
Previous research on Swedish market towns in the pre-industrial era suggests that approximately 65 kilometers was the maximum distance that a horse-drawn cart could travel in a day (Bergenfeldt 2014, 131-133). Adding the assumption that an inspector would want to return to his home within a day, we assume that deaneries further away than 30 kilometers from the school inspector's home were very difficult to reach comfortably - especially considering the fact that the inspector also needed some time to perform the actual inspection. Since the 30-kilometer cut-off is, if anything, likely to be overly generous, we also try an alternative cut-off of 20 kilometers. We expect the coefficient $\beta_{2}$ to be positive, since a nearby inspector was more effective than a remote one, and we expect the coefficient $\beta_{3}$ to be negative since the railroad is unlikely to have mattered much for school outcomes in areas that were easily accessed by other means of transportation.

The last model that we estimate offers us the most conservative test of our main hypotheses. As we discussed earlier, the railroad had many different sorts of effects in the connected villages, towns, and cities, and we wish to distinguish between all those other more indirect effects and the direct effect of the railroad on the effectiveness of the school inspectors. Here, we exploit the fact that some deaneries with a train station within their borders were inspected by school inspectors who did not themselves live in a deanery that was connected to the rail network. By including both the Railroad variable from equation (1) and the Connection variable that we rely on otherwise in the same model, we are able to estimate the effect of a railroad connection to the inspector while controlling for the presence of the railroad as such.

$$
\begin{aligned}
y_{i} & =\alpha+\beta_{0} \text { Railroad }_{i}+\beta_{1} \text { Connection }_{i}+\beta_{2} \text { Within } 30 \mathrm{~km}_{i} \\
& +\beta_{3} \text { Connection }_{i} \times \text { Within } 30 \mathrm{~km}_{i}+\gamma \mathbf{X}_{i}+\epsilon_{i}
\end{aligned}
$$

Including both Connection and Railroad in the model is a powerful test since it is hard to see why the effects of the railroad in locality $A$ should depend on whether locality $B$, where the school inspector lived, was also connected to the railroad - unless, or course, the railroad mattered to the school inspector's activities, as we believe it did.

Figure 2 explains the construction of the main variables of interest, using the example of Peter Wingren, a school inspector who lived in the city of Lund in 1868. Inspector Wingren was responsible for inspection of six deaneries in the diocese of Lund (but unfortunately not the one in Lund itself, where he lived, since it was the responsibility of another inspector, who also lived in Lund). Assuming that Wingren was willing to travel up to 30 kilometers by horse of foot, as we discussed above, he could reach three of the six deaneries comfortably without relying on the railroad: Skytts, Wemmenhögs, and Oxie (but note that Oxie, to which Wingren could also travel by train, includes the major city of Malmö, and is thus excluded from our analyses). The other three deaneries were further away, but Inspector Wingren was luckier than some other inspectors, for he could use the railroad to reach two of them: the Luggude deanery and the Ljunits och Herrestads deanery both had train stations. Unfortunately, it was not at all easy for Inspector Wingren to reach Södra Åsbo, which was located 44 kilometers from his home in Lund and which did not have a train station.

We will now proceed to discuss the control variables that are included in the vector $\mathbf{X}$. Our estimation strategy relies, in part, on the assumption that the development of the railroad network in 1868 was largely independent of the previous level of economic and political development in the connected localities, as suggested by Fig. 1. But we nevertheless control for several potential confounders in our regression analyses.

In spite of the evidence in panel A in Fig. 1, we control for prior levels of economic development. If railroad lines were at least in some cases drawn through richer or faster-growing areas, higher demand for education in some regions might be caused by those innate economic 


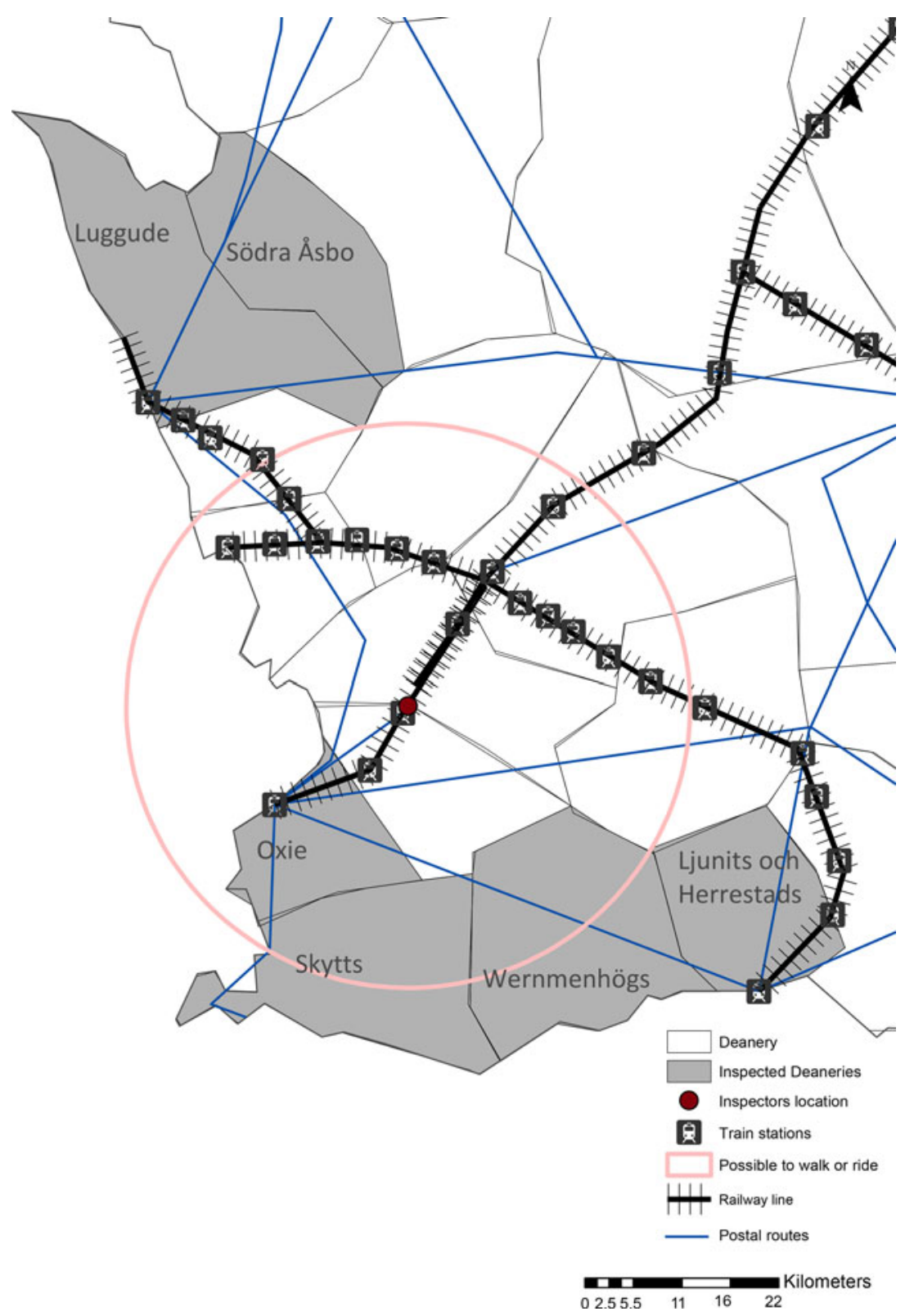

Figure 2. Inspector wingren's travels.

differences. To control for these economic effects, we rely on data on regional GDP per capita at the county level in 1860 from Enflo, Henning, and Schön (2014); we adapt the data for Sweden's twenty-four counties to the borders of our deaneries using GIS methods. Moreover, we control for urbanization by adding a dummy variable that takes the value 1 if there was a town holding administrative township rights within the deanery (and 0 otherwise). Although Swedish towns were tiny by international standards (most of them did not reach the population threshold of 5,000 inhabitants often used in the international literature to define a 'town'), urban areas might have been more modern and hence prone to supply more education than rural deaneries, as well as being more likely to have railroad access. 
We also control for prior political development, in spite of the evidence in panel B in Fig. 1. Specifically, we include a measure of the number of postal rays per deanery to proxy for preindustrial state capacity. Since this variable is not a perfect proxy for pre-treatment state capacity, we also control for two geographical variables: the ruggedness of terrain, specifically the standard deviation of elevation in each deanery (Nunn and Puga 2012), and the distance, in hundreds of kilometers, from Sweden's capital, Stockholm. We do not think that the ruggedness variable influenced the quality of teaching by increasing travel times, for the school students; instead, we wish to use ruggedness as another proxy for pre-treatment levels of state capacity.

In addition, we add a control variable that measures the effect of the power of landed elites over the provison of schooling. The literature about the potential effects of elites on schooling is large but inconclusive. Important studies suggest that landed elites often blocked the introduction of public schooling when they had the power to do so (see, for example, Engerman and Sokoloff 1994, Lindert 2004, and Galor, Moav, and Vollrath 2009). However, a recent study of rural parishes in Sweden in the late nineteenth century suggests that local elites in fact promoted investments in primary schooling (Andersson and Berger 2018). To control for the power of landed elites, we collect data on the share of the rural population with voting rights by digitizing a map from official statistical publications.

We also wish to consider the possibility that the main town in each diocese - the seat of the bishop - might have differed from other localities in the willingness of local decision-makers to supply different forms of state-sponsored education. We therefore control for the seats of Sweden's bishops in 1868.

Finally, we add controls for railroad lines that were planned but not yet built by the year 1868 . As we discussed earlier, the inclusion of this variable allows us to perform a placebo test. According to our theory, the mere expectation that a deanery would soon become connected to the railroad network should not influence school outcomes much; what mattered, in our view, was the effect an actual railroad had on the school inspector's ability to carry out his duties. We therefore expect the future-railroad placebo variable to be only weakly related with the outcome variables of interest.

There were 36 inspectors in total during our period of study. They were either priests or had a career in teaching and teaching administration. One potential methodological concern for our study is that if the assignment of inspectors to deaneries was based on the political preferences of local, regional, and national decision makers, this process, and not the railroad, might explain the patterns we observe. But we have found no evidence of this sort of political bargaining process in the historical literature we have consulted. The inspectors were largely chosen on basis of their high social prestige and their ability to devote time and resources to their tasks. Nevertheless, since the unobserved individual characteristics of the inspectors are likely to have mattered to how they performed his duties, we cluster the standard errors at the inspector level in all our models. The clustering also helps to address another important aspect of the problem we are studying: the fact that the performance of the inspections depended on the time-allocation budget of each school inspector. If a railroad connection increased the efficiency with which an inspector could oversee one connected school district, this likely also increased the time left for inspecting other schools, including schools without a rail connection. In that important sense, school districts that were inspected by the same inspector were clearly not independent observations.

\section{Permanent Schools}

The first of the two main ideas we wish to test is that having a school inspector who was able to travel via the railroad network increased the proportion of children who attended permanent public schools. Note that the idea is not that the railroad increased the likelihood that students made it to school, for students did not in fact travel very far, even in the nineteenth century 
(data from 1868 suggest that the number of children who walked more than half a mile to get to school was only 9.4 per cent in deaneries that were not connected to the railroad network and 13.2 per cent in deaneries that were). Our idea is rather that the presence of a school inspector who could get easily to the inspected schools increased the likelihood that education was provided in the favored form of permanent public schools. ${ }^{4}$

For descriptive evidence, see the map in Fig. 3, which shows that the proportion of children who attended permanent public schools was typically higher in areas that were close to the first railroads. In this figure, the share of school-age children who went to public schools is visibly higher in deaneries that the school inspector could get to easily than in deaneries that were remote and had no railroad connection.

The results of our regression analyses can be found in Table 2. In column 1, we estimate a model without control variables that simply includes the dummy variable 'Railroad Connection,' which, as we have mentioned, takes the value 1 if there was a train station in the inspected deanery and in the deanery where the school inspector lived. As Table 2 shows, the estimated coefficient is approximately 17: In other words, this simple analysis suggests that the proportion of children in permanent schools was approximately 17 per cent higher if the inspector could get to a school district by train.

In column 2 , we include the control variables, which behave very similarly across specifications. High levels of GDP per capita are consistently correlated with the provision of public education. The estimated difference between towns and other localities is small, but in the expected (positive) direction. Neither of the three variables that we have included to control for pretreatment levels of state capacity - early-modern postal-system density, rugged terrain, and the distance to Stockholm, are clearly associated with a higher share of children in permanent schools. Neither is political participation, and although being in the vicinity of the bishop's office is associated with more children attending permanent schools, this correlation is very imprecisely estimated. Finally, it is reassuring to find that there is no clear relationship at all between planned railways - the placebo test we discussed earlier - and the share of children in permanent public schools.

The model in column 2 does not take into account the important fact that some school inspectors lived so close to the schools they inspected that they could reach at least some of their assigned districts easily without traveling by train. In column 3 , we add a variable that takes the value 1 if the inspector lived within $30 \mathrm{~km}$ of the centroid of the inspected deanery. We then interact the 'Railroad Connection' variable with this new dummy variable, since we expect different forms of travel to be substitutes, not complements. As expected, the coefficient for the interaction term is negative, which means that if the inspector lived nearby, outcomes were not improved much by the fact that he could also travel by train. Meanwhile, the coefficient for the variable 'Railroad Connection' variable and the coefficient for the variable 'Inspector Within $30 \mathrm{~km}$ ' are both positive, suggesting that education outcomes were improved if the inspector either lived nearby or could travel to the inspected deanery by train. In column 4 , we run the same specification, but we now use a 20-kilometer threshold instead of a 30-kilometer threshold. This decreases the size of the coefficient slightly, but the qualitative interpretation remains the same.

Finally, in column 5 and 6, we take into account that deaneries with stations that were connected to the railroad network might have had larger shares of children in permanent schools due to the general modernizing effects of the new transportation technology, not because the school inspector had better travel options. To account for such general effects of the railroad, we now add a dummy for the presence of a railway station in the expected deanery as a control.

\footnotetext{
${ }^{4}$ Although historical evidence suggests that teachers were recruited locally, a railroad connection could have been important for broader recruitment and teacher quality. While this alternative mechanism might have influenced the curriculum taught in the schools, there are less reasons to believe that it impacted directly on our main variable of interest: the share of children in permanent schools.
} 


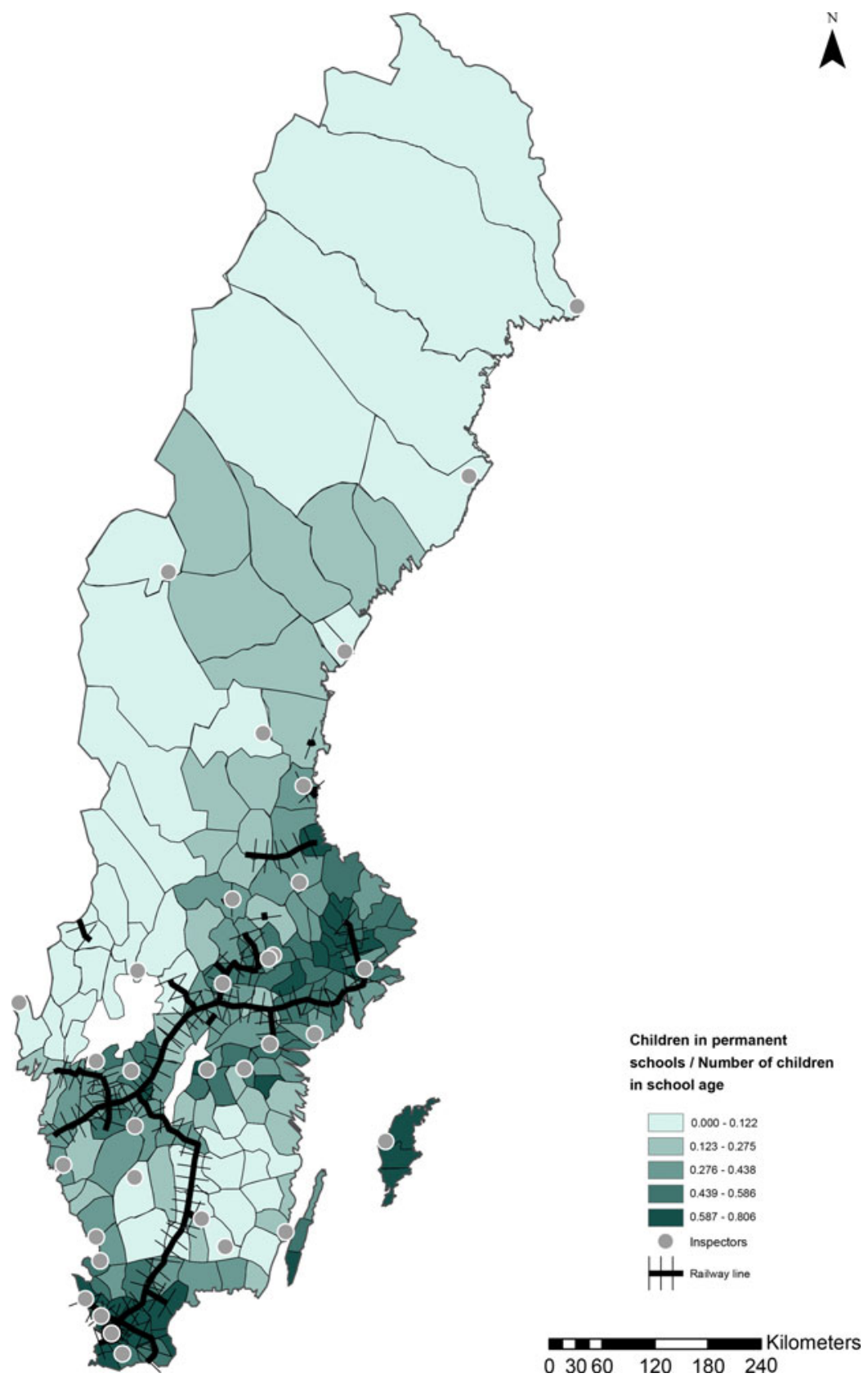

Figure 3. Share of children in permanent schools.

The coefficient for this variable is small and imprecisely estimated, which strongly suggests that merely having a train station did not contribute much to education outcomes. What seems to matter in these models, as before, is whether the school inspector was able to travel by train to the deaneries he inspected: the variable 'Railroad Connection' remains large, positive, and relatively precisely estimated. Again, the estimated effect of a railroad connection turns out to be somewhat larger when we allow for a more generous definition of living nearby (30 kilometers, as opposed to 20). 
Table 2. Regression analyses: children in permanent public schools

\begin{tabular}{|c|c|c|c|c|c|c|}
\hline & 1 & 2 & 3 & 4 & 5 & 6 \\
\hline Railroad connection & $\begin{array}{l}16.7^{\star \star} \\
(6.4)\end{array}$ & $\begin{array}{l}14.4^{\star \star} \\
(5.8)\end{array}$ & $\begin{array}{l}18.4^{\star \star \star} \\
(5.9)\end{array}$ & $\begin{array}{l}16.3^{\star \star *} \\
(5.3)\end{array}$ & $\begin{array}{l}16.9^{\star \star} \\
(6.8)\end{array}$ & $\begin{array}{l}15.3^{\text {** }} \\
(6.5)\end{array}$ \\
\hline Inspector within $30 \mathrm{~km}$ & & & $\begin{array}{c}8.2^{\star} \\
(4.4)\end{array}$ & & $\begin{array}{c}8.4^{\star} \\
(4.4)\end{array}$ & \\
\hline Connection $\times$ Within $30 \mathrm{~km}$ & & & $\begin{array}{r}-11.6 \\
(8.5)\end{array}$ & & $\begin{array}{r}-11.8 \\
(8.6)\end{array}$ & \\
\hline Inspector within $20 \mathrm{~km}$ & & & & $\begin{array}{c}4.3 \\
(4.6)\end{array}$ & & $\begin{array}{c}4.4 \\
(4.7)\end{array}$ \\
\hline Connection $\times$ Within $20 \mathrm{~km}$ & & & & $\begin{array}{c}-7.5 \\
(8.1)\end{array}$ & & $\begin{array}{c}-7.6 \\
(8.2)\end{array}$ \\
\hline Railroad & & & & & $\begin{array}{c}2.5 \\
(4.8)\end{array}$ & $\begin{array}{c}1.7 \\
(4.8)\end{array}$ \\
\hline Regional GDP per Capita in 1860 & & $\begin{array}{l}11.3^{\star \star} \\
(4.4)\end{array}$ & $\begin{array}{l}11.8^{\star \star} \\
(4.5)\end{array}$ & $\begin{array}{l}11.6^{\star \star} \\
(4.4)\end{array}$ & $\begin{array}{l}11.7^{\star \star} \\
(4.5)\end{array}$ & $\begin{array}{l}11.5^{\star \star} \\
(4.4)\end{array}$ \\
\hline Town & & $\begin{array}{c}2.8 \\
(3.5)\end{array}$ & $\begin{array}{c}2.7 \\
(3.4)\end{array}$ & $\begin{array}{c}2.7 \\
(3.5)\end{array}$ & $\begin{array}{c}2.6 \\
(3.4)\end{array}$ & $\begin{array}{c}2.6 \\
(3.5)\end{array}$ \\
\hline Early-modern postal network density & & $\begin{array}{c}-0.1 \\
(1.8)\end{array}$ & $\begin{array}{c}-0.4 \\
(1.7)\end{array}$ & $\begin{array}{c}-0.2 \\
(1.8)\end{array}$ & $\begin{array}{c}-0.6 \\
(1.8)\end{array}$ & $\begin{array}{c}-0.3 \\
(1.8)\end{array}$ \\
\hline Rugged terrain & & $\begin{array}{c}-1.1 \\
(0.8)\end{array}$ & $\begin{array}{c}-1.0 \\
(0.8)\end{array}$ & $\begin{array}{c}-1.0 \\
(0.8)\end{array}$ & $\begin{array}{c}-1.0 \\
(0.8)\end{array}$ & $\begin{array}{c}-1.0 \\
(0.8)\end{array}$ \\
\hline Distance to stockholm (100s of $\mathrm{km}$ ) & & $\begin{array}{c}-1.7 \\
(2.4)\end{array}$ & $\begin{array}{c}-1.6 \\
(2.3)\end{array}$ & $\begin{array}{c}-1.7 \\
(2.4)\end{array}$ & $\begin{array}{c}-1.6 \\
(2.3)\end{array}$ & $\begin{array}{c}-1.7 \\
(2.4)\end{array}$ \\
\hline Political participation & & $\begin{array}{c}3.2 \\
(10.6)\end{array}$ & $\begin{array}{c}2.1 \\
(9.7)\end{array}$ & $\begin{array}{c}3.5 \\
(10.7)\end{array}$ & $\begin{array}{l}1.9 \\
(9.6)\end{array}$ & $\begin{array}{c}3.3 \\
(10.6)\end{array}$ \\
\hline Seat of bishop & & $\begin{array}{c}1.6 \\
(6.1)\end{array}$ & $\begin{array}{c}2.0 \\
(5.7)\end{array}$ & $\begin{array}{c}2.3 \\
(6.3)\end{array}$ & $\begin{array}{c}2.2 \\
(5.7)\end{array}$ & $\begin{array}{c}2.5 \\
(6.2)\end{array}$ \\
\hline Placebo (Future Railway) & & $\begin{array}{c}-1.2 \\
(5.0)\end{array}$ & $\begin{array}{c}-1.3 \\
(5.0)\end{array}$ & $\begin{array}{c}-1.3 \\
(5.0)\end{array}$ & $\begin{array}{c}-0.5 \\
(5.2)\end{array}$ & $\begin{array}{c}-0.7 \\
(5.2)\end{array}$ \\
\hline Constant & $\begin{array}{l}31.4^{\star \star \star} \\
(4.5)\end{array}$ & $\begin{array}{c}13.7 \\
(15.2)\end{array}$ & $\begin{array}{c}11.9 \\
(15.0)\end{array}$ & $\begin{array}{c}12.7 \\
(15.1)\end{array}$ & $\begin{array}{c}11.5 \\
(14.8)\end{array}$ & $\begin{array}{c}12.4 \\
(14.9)\end{array}$ \\
\hline $\mathrm{N}$ & 170 & 170 & 170 & 170 & 170 & 170 \\
\hline
\end{tabular}

${ }^{\star} p<0.10,{ }^{\star \star} p<0.05,{ }^{\star \star \star} p<0.01$. Standard errors in parentheses (clustered on inspectors).

As Table 3 shows, the relationship between a railway connection allowing an inspector to travel to remote schools and the proportion of children in ambulatory schools - the school form that the inspectors were most critical of and that the national government wished to phase out - is the exact opposite of the relationship between a railway connection and the proportion of children in permanent schools.

The other school forms listed in Table 1 are less relevant for our argument, but we include analyses of each of these school forms in the Supplementary Material. There is no clear relationship between the railroads and those school forms, except for the elementary schools (småskolor), which were preparatory schools for children who were, for various reasons, not deemed ready to enroll in a regular public school. These schools were usually staffed by less well-educated teachers, and historical studies suggest that they were often introduced as a second-best solution to reduce salary costs and increase public acceptance in areas where schooling was resisted (see especially Evertsson 2012). These findings strengthen our interpretation of the effects of the railroad: when the inspector could travel to remote schools via the railroads, fewer children attended elementary schools, just as fewer children attended ambulatory schools.

\section{The Curriculum}

The historical literature on the Swedish education system suggests that school inspectors encouraged local teachers to teach secular, state-building subjects - especially geography and history - 
Table 3. Regression analyses: children in ambulatory schools

\begin{tabular}{|c|c|c|c|c|c|c|}
\hline & 1 & 2 & 3 & 4 & 5 & 6 \\
\hline Railroad connection & $\begin{array}{r}-10.3^{\star} \\
(5.7)\end{array}$ & $\begin{array}{c}-11.5^{\star \star} \\
(5.4)\end{array}$ & $\begin{array}{c}-15.6^{\star \star \star} \\
(5.6)\end{array}$ & $\begin{array}{c}-13.6^{\star \star \star} \\
(5.0)\end{array}$ & $\begin{array}{c}-14.0^{\star *} \\
(6.3)\end{array}$ & $\begin{array}{c}-12.4^{\star \star} \\
(6.1)\end{array}$ \\
\hline Inspector within 30 km & & & $\begin{array}{r}-9.0^{\star} \\
(4.9)\end{array}$ & & $\begin{array}{r}-9.2^{\star} \\
(5.0)\end{array}$ & \\
\hline Connection $\times$ Within $30 \mathrm{~km}$ & & & $\begin{array}{r}12.0^{*} \\
(6.6)\end{array}$ & & $\begin{array}{r}12.3^{\star} \\
(6.6)\end{array}$ & \\
\hline Inspector within 20 km & & & & $\begin{array}{c}-7.8 \\
(5.7)\end{array}$ & & $\begin{array}{c}-7.9 \\
(5.8)\end{array}$ \\
\hline Connection $\times$ Within $20 \mathrm{~km}$ & & & & $\begin{array}{c}9.7 \\
(6.8)\end{array}$ & & $\begin{array}{c}9.9 \\
(6.9)\end{array}$ \\
\hline Railroad & & & & & $\begin{array}{c}-2.6 \\
(4.5)\end{array}$ & $\begin{array}{c}-2.0 \\
(4.6)\end{array}$ \\
\hline Regional GDP per Capita in 1860 & & $\begin{array}{c}-9.6^{\star \star} \\
(3.7)\end{array}$ & $\begin{array}{c}-10.1^{\star *} \\
(3.7)\end{array}$ & $\begin{array}{c}-9.9^{\star \star} \\
(3.7)\end{array}$ & $\begin{array}{c}-10.0^{\star \star} \\
(3.8)\end{array}$ & $\begin{array}{c}-9.8^{\star \star} \\
(3.8)\end{array}$ \\
\hline Town & & $\begin{array}{c}-5.4 \\
(3.3)\end{array}$ & $\begin{array}{c}-5.2 \\
(3.3)\end{array}$ & $\begin{array}{c}-4.9 \\
(3.4)\end{array}$ & $\begin{array}{c}-5.1 \\
(3.3)\end{array}$ & $\begin{array}{c}-4.8 \\
(3.4)\end{array}$ \\
\hline Early-modern postal network density & & $\begin{array}{c}-0.9 \\
(1.9)\end{array}$ & $\begin{array}{c}-0.6 \\
(1.8)\end{array}$ & $\begin{array}{c}-0.7 \\
(1.9)\end{array}$ & $\begin{array}{c}-0.4 \\
(1.9)\end{array}$ & $\begin{array}{c}-0.6 \\
(1.9)\end{array}$ \\
\hline Rugged terrain & & $\begin{array}{c}0.2 \\
(0.7)\end{array}$ & $\begin{array}{c}0.1 \\
(0.7)\end{array}$ & $\begin{array}{c}0.1 \\
(0.7)\end{array}$ & $\begin{array}{c}0.1 \\
(0.7)\end{array}$ & $\begin{array}{c}0.1 \\
(0.7)\end{array}$ \\
\hline Distance to stockholm (100s of $\mathrm{km}$ ) & & $\begin{array}{c}-0.4 \\
(2.3)\end{array}$ & $\begin{array}{c}-0.5 \\
(2.2)\end{array}$ & $\begin{array}{c}-0.4 \\
(2.3)\end{array}$ & $\begin{array}{c}-0.5 \\
(2.2)\end{array}$ & $\begin{array}{c}-0.4 \\
(2.3)\end{array}$ \\
\hline Political participation & & $\begin{array}{l}-5.9 \\
(10.2)\end{array}$ & $\begin{array}{c}-4.6 \\
(9.1)\end{array}$ & $\begin{array}{l}-6.1 \\
(10.1)\end{array}$ & $\begin{array}{c}-4.4 \\
(9.0)\end{array}$ & $\begin{array}{l}-5.9 \\
(10.1)\end{array}$ \\
\hline Seat of bishop & & $\begin{array}{c}0.6 \\
(5.5)\end{array}$ & $\begin{array}{c}0.2 \\
(5.0)\end{array}$ & $\begin{array}{c}-0.1 \\
(5.4)\end{array}$ & $\begin{array}{c}-0.0 \\
(5.0)\end{array}$ & $\begin{array}{c}-0.3 \\
(5.4)\end{array}$ \\
\hline Placebo (Future Railway) & & $\begin{array}{c}-1.9 \\
(4.8)\end{array}$ & $\begin{array}{c}-1.9 \\
(4.7)\end{array}$ & $\begin{array}{c}-1.8 \\
(4.6)\end{array}$ & $\begin{array}{c}-2.7 \\
(5.5)\end{array}$ & $\begin{array}{c}-2.5 \\
(5.5)\end{array}$ \\
\hline Constant & $\begin{array}{l}22.7^{\star \star \star} \\
(4.1)\end{array}$ & $\begin{array}{l}56.5^{\star \star \star} \\
(16.3)\end{array}$ & $\begin{array}{l}58.4^{\star \star \star} \\
(16.1)\end{array}$ & $\begin{array}{l}57.9^{\star \star \star} \\
(16.1)\end{array}$ & $\begin{array}{l}58.7^{\star \star \star} \\
(16.0)\end{array}$ & $\begin{array}{l}58.1^{\star \star \star} \\
(16.0)\end{array}$ \\
\hline $\mathrm{N}$ & 170 & 170 & 170 & 170 & 170 & 170 \\
\hline
\end{tabular}

${ }^{\star} p<0.10,{ }^{\star \star} p<0.05,{ }^{* \star \star} p<0.01$. Standard errors in parentheses (clustered on inspectors).

while downplaying the role of the Catechism. There were widespread concerns, at the time, that the church-run public schools merely encouraged repetitive memorization of the Catechism at the expense of modern forms of teaching in non-religious subjects.

For descriptive evidence on the relationship between the location of the school inspectors, railroad access, and the proportion of children who studied geography and history relative to the proportion of children who studied the Catechism, see the map in Fig. 4. As in Fig. 3, there appears to be a strong correlation between railroad access and education outcomes (here, the share of children who were taught geography and history, relative to the number who were taught the Catechism). Interestingly, the higher relative share of students who studied geography and history in the railroad-connected deaneries was not because the share of children who studied the Catechism was lower. Almost all children studied the Catechism, but children in deaneries that the inspector could get to easily also studied other things.

Table 4 analyzes the evidence in Fig. 4 using statistical methods. The positive coefficients for the variables Railroad Connection and Within 30 kilometers suggest that, as expected, deaneries whose inspector was able to travel by train, or whose inspector lived close enough to walk or ride, were taught more geography and history - subjects that school inspectors were particularly keen to promote. But the coefficients are estimated with less precision than in our previous analyses, making us less confident in a causal interpretation of the observed correlations.

When analyzing the data in more detail, we follow the same empirical strategy that we followed in the previous section. Thus, in column 1, we simply include the Railroad Connection 

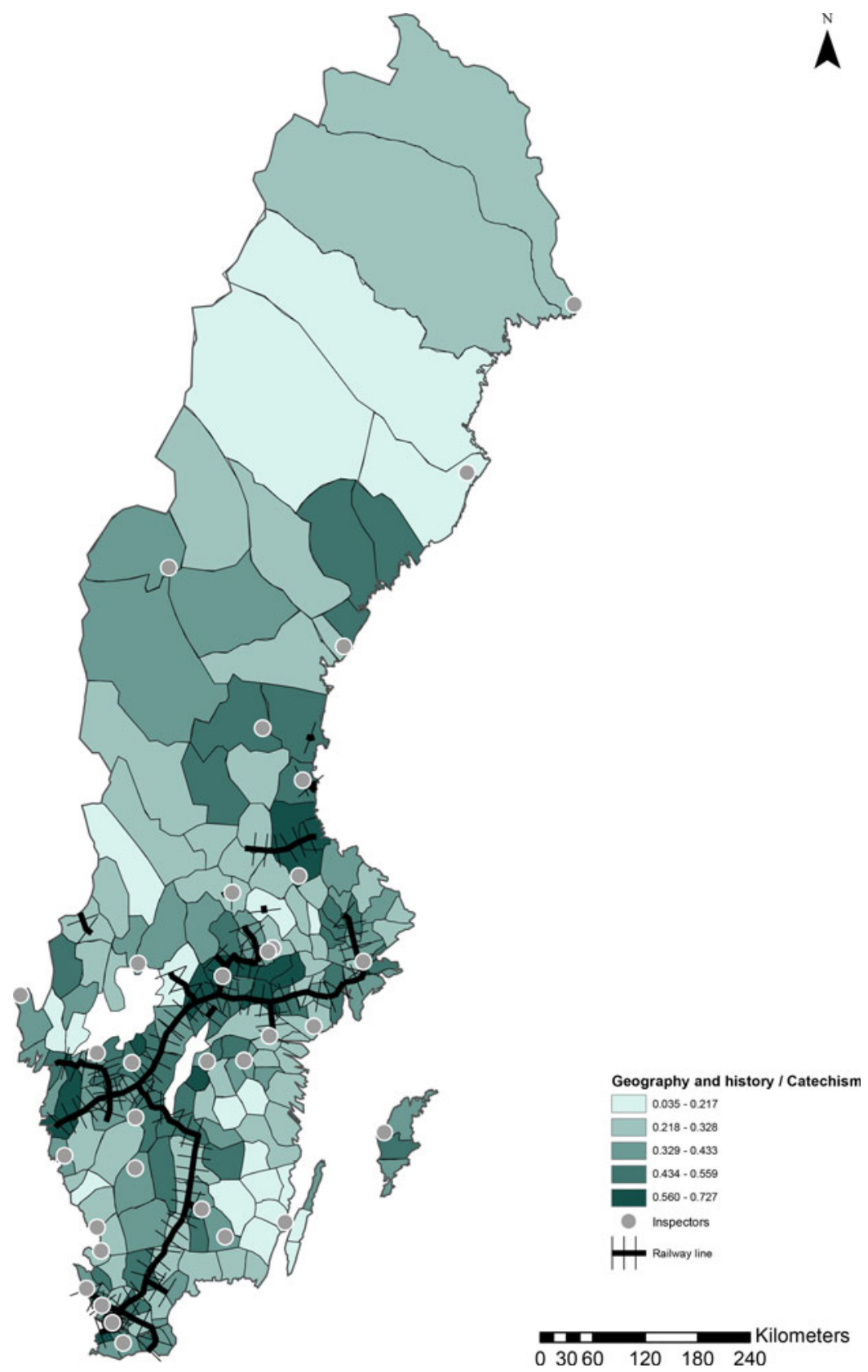

Figure 4. Geography and history relative to Catechism.

variable without adding controls. The coefficient for having a railroad connection on the proportion of children who followed the broader curriculum that was promoted by the national government is large and statistically significant. ${ }^{5}$ In column 2 , we add the control variables. The magnitude of the coefficient for Railroad Connection decreases somewhat when the controls

\footnotetext{
${ }^{5}$ The mean of the dependent variable is 37 , and its standard deviation is 13 . The interpretation of the coefficient is that deaneries within reach of school inspectors were on average 9.2 points higher on this relative scale.
} 
Table 4. Regression analyses: geography and history

\begin{tabular}{|c|c|c|c|c|c|c|}
\hline & 1 & 2 & 3 & 4 & 5 & 6 \\
\hline Railroad connection & $\begin{array}{l}9.2^{\star \star \star} \\
(2.7)\end{array}$ & $\begin{array}{l}5.5^{\star} \\
(3.2)\end{array}$ & $\begin{array}{l}7.1^{*} \\
(3.9)\end{array}$ & $\begin{array}{l}5.8^{*} \\
(3.4)\end{array}$ & $\begin{array}{c}6.4 \\
(4.8)\end{array}$ & $\begin{array}{c}5.2 \\
(4.3)\end{array}$ \\
\hline Inspector within $30 \mathrm{~km}$ & & & $\begin{array}{c}3.0 \\
(2.8)\end{array}$ & & $\begin{array}{c}3.1 \\
(2.9)\end{array}$ & \\
\hline Connection $\times$ Within $30 \mathrm{~km}$ & & & $\begin{array}{c}-4.5 \\
(3.9)\end{array}$ & & $\begin{array}{c}-4.6 \\
(3.9)\end{array}$ & \\
\hline Inspector within $20 \mathrm{~km}$ & & & & $\begin{array}{c}2.2 \\
(3.7)\end{array}$ & & $\begin{array}{c}2.2 \\
(3.8)\end{array}$ \\
\hline Connection $\times$ Within $20 \mathrm{~km}$ & & & & $\begin{array}{c}-2.0 \\
(4.4)\end{array}$ & & $\begin{array}{c}-2.1 \\
(4.4)\end{array}$ \\
\hline Railroad & & & & & $\begin{array}{c}1.2 \\
(3.3)\end{array}$ & $\begin{array}{c}0.9 \\
(3.4)\end{array}$ \\
\hline Regional GDP per Capita in 1860 & & $\begin{array}{c}0.3 \\
(1.7)\end{array}$ & $\begin{array}{c}0.5 \\
(1.7)\end{array}$ & $\begin{array}{c}0.4 \\
(1.7)\end{array}$ & $\begin{array}{c}0.4 \\
(1.7)\end{array}$ & $\begin{array}{c}0.3 \\
(1.8)\end{array}$ \\
\hline Town & & $\begin{array}{c}-1.8 \\
(1.8)\end{array}$ & $\begin{array}{c}-1.8 \\
(1.9)\end{array}$ & $\begin{array}{c}-2.0 \\
(1.9)\end{array}$ & $\begin{array}{c}-1.9 \\
(1.9)\end{array}$ & $\begin{array}{c}-2.0 \\
(1.9)\end{array}$ \\
\hline Early-modern postal network density & & $\begin{array}{l}1.8^{\star} \\
(0.9)\end{array}$ & $\begin{array}{c}1.7^{\star} \\
(1.0)\end{array}$ & $\begin{array}{c}1.7^{\star} \\
(1.0)\end{array}$ & $\begin{array}{c}1.6 \\
(1.0)\end{array}$ & $\begin{array}{c}1.7^{\star} \\
(0.9)\end{array}$ \\
\hline Rugged terrain & & $\begin{array}{c}-1.1^{\star *} \\
(0.4)\end{array}$ & $\begin{array}{c}-1.0^{\star *} \\
(0.4)\end{array}$ & $\begin{array}{c}-1.1^{\star \star} \\
(0.4)\end{array}$ & $\begin{array}{c}-1.0^{\star \star} \\
(0.4)\end{array}$ & $\begin{array}{c}-1.0^{\star \star} \\
(0.4)\end{array}$ \\
\hline Distance to stockholm (100s of km) & & $\begin{array}{c}2.2 \\
(1.4)\end{array}$ & $\begin{array}{c}2.2 \\
(1.4)\end{array}$ & $\begin{array}{c}2.2 \\
(1.4)\end{array}$ & $\begin{array}{c}2.3 \\
(1.4)\end{array}$ & $\begin{array}{c}2.2 \\
(1.4)\end{array}$ \\
\hline Political participation & & $\begin{array}{c}4.7 \\
(7.9)\end{array}$ & $\begin{array}{c}4.3 \\
(7.6)\end{array}$ & $\begin{array}{c}4.7 \\
(8.0)\end{array}$ & $\begin{array}{c}4.2 \\
(7.6)\end{array}$ & $\begin{array}{c}4.7 \\
(8.0)\end{array}$ \\
\hline Seat of bishop & & $\begin{array}{c}3.0 \\
(3.5)\end{array}$ & $\begin{array}{c}3.2 \\
(3.4)\end{array}$ & $\begin{array}{c}3.1 \\
(3.6)\end{array}$ & $\begin{array}{c}3.3 \\
(3.4)\end{array}$ & $\begin{array}{c}3.2 \\
(3.7)\end{array}$ \\
\hline Placebo (Future Railway) & & $\begin{array}{c}-4.2^{\star \star} \\
(1.9)\end{array}$ & $\begin{array}{c}-4.2^{\star *} \\
(1.9)\end{array}$ & $\begin{array}{c}-4.2^{\star \star} \\
(1.9)\end{array}$ & $\begin{array}{r}-3.8^{\star} \\
(2.0)\end{array}$ & $\begin{array}{r}-3.9^{*} \\
(2.0)\end{array}$ \\
\hline Constant & $\begin{array}{l}34.7^{\star \star \star} \\
(1.6)\end{array}$ & $\begin{array}{l}26.0^{\star \star \star} \\
(9.5)\end{array}$ & $\begin{array}{l}25.3^{\star \star} \\
(9.5)\end{array}$ & $\begin{array}{l}25.7^{\star \star} \\
(9.8)\end{array}$ & $\begin{array}{l}25.2^{\star \star} \\
(9.5)\end{array}$ & $\begin{array}{c}25.6^{\star \star} \\
(9.8)\end{array}$ \\
\hline $\mathrm{N}$ & 170 & 170 & 170 & 170 & 170 & 170 \\
\hline
\end{tabular}

${ }^{\star} \mathrm{p}<0.10,{ }^{\star \star} \mathrm{p}<0.05,{ }^{\star \star \star} \mathrm{p}<0.01$. Standard errors in parentheses (clustered on inspectors).

are included. In column 3, we add information about the distance between the inspected deanery and the inspector's home. The coefficient remains large and is relatively precisely estimated (although the p-value is greated than .05). The negative interaction term again suggests that different forms of travel were substitutes, not complements. In column 4 , we show that the effects are essentially similar when we use the 20-kilometer cut-off instead of the 30-kilometer cut-off.

Finally, in columns 5 and 6, we take into account that access to the railroad network might have influenced education outcomes through the generally modernizing effects that were brought by this new transportation technology, not because inspectors had better travel options. By including the variable Railroad as a control, we separate the association that is due to the inspector's travel options from many other potential effects of the railroad in the inspected deanery. As in the previous section, most of the estimated effect seems to be due to the fact that the inspector could get to the schools easily, not to the mere presence of the railroad, but the coefficient for Railroad Connection nevertheless drops in size and becomes less precisely estimated $(p \approx 0.2)$. This means that the results regarding the content of the curriculum are significantly less robust than the results regarding the provision of education per se, which we discussed in the previous section, although it remains more likely than not that the railroad strengthened the nation state in this respect as well.

In the Supplementary Material, we include similar analyses of the other subjects in the curriculum: arithmetic, geometry, natural science, physical education, religious history, reading, singing, and writing. The results are consistently less robust than the results for geography and history (which were the subjects that school inspectors were most eager to promote according to the historical literature we discussed earlier). It is worth noting, however, that a railway 
connection for the inspector is positively associated with more students taking geometry, natural science, physical education, and writing, but with fewer students taking reading, religious history, and singing. The school inspectors were known to favor the subjects in the first group, whereas the subjects in the second group were compulsory for all students (with the exception of singing in 'hopeless cases'), and they were favored by local priests since they were essential parts of religious upbringing (reading the Bible was encouraged in the Lutheran tradition, which explains why the estimated effects of the railroad are different for reading and writing). We do not wish to make too much of these observations, however, since the coefficients are small and not precisely estimated.

\section{Conclusions}

In this paper, we have examined the relationship between one of the defining technological innovations of the First Industrial Revolution - the railroad - and one of the most momentous social and political changes of the nineteenth century - the expansion of primary education and the introduction of national school curricula. To accomplish this goal, we have combined geographic-information-system data on the extent of the Swedish railroad network in the second half of the nineteenth century with fine-grained, official data on the provision of primary education in different localities in the late 1860s, allowing us to examine how the coming of railroads related not only to the provision of education per se, but also to the content of the curriculum.

Our results strongly suggest that the coming of the railroad strengthened the nation state vis-à-vis the local, religious authorities that had long controlled primary education. By comparing nearby school districts that national inspectors could get to easily from their homes, remote school districts that were reachable by train, and remote school districts that were not reachable by train, we have provided evidence on how the railroad mattered for the effectiveness of state bureaucracies in the nineteenth-century world. We find that the railroad was positively associated with the proportion of students in permanent public schools. Because of the specific historical circumstances during the railroad network roll-out, the detail of the geographical data, and the inclusion of several control variables, we argue that it is possible to make causal claims on the basis of the estimated correlations. We also find that the railroad was positively associated with the relative share of children that were taught the subjects that the modernizing nation state was keen to promote: geography and history. The causal interpretation of those findings is more uncertain, however.

There are strong reasons to believe that if these sorts of results hold for Sweden - where the relationship between church and state was comparatively harmonious since the Swedish church had been a state church since the sixteenth century (cf. Morgan 2002) - they can also be generalized to other countries in Western Europe and elsewhere. In other words, our paper strongly suggest that the railroad, a nineteenth-century technological innovation, had important political effects, confirming the ideas of social scientists such as Samuel Finer, Michael Mann, and John Hicks about the modern nation-state's dependence on quintessentially modern technologies.

More generally, our findings suggest that technological innovations in the nineteenth century had a powerful direct effect on state capacity: the ability of state agents to exercise control over persons, activities, and resources, and enforce government policies. Existing theories of state capacity in economics and political science rightly emphasize the strategic interaction among political parties (Besley and Persson 2011) and the political struggle for control between local and national elites (Soifer 2015). Our results suggest that modern technologies such as the railroad sharpened those conflicts by making it technically feasible for the state's agents to exercise control in the first place. These ideas and findings about communication technologies are likely to be generalizable to other situations in which state capacity depends on the government's ability to monitor local authorities or private organizations that carry out public functions. Technology 
is also likely to matter for state capacity in other ways, but that more general idea awaits further development and testing.

Author contributions. Authors have contributed to the article equally.

Conflicts of interest. There are no conflicts of interest.

Ethical standards. Ethical standards have been met since the information is publicly available for anyone.

Supplementary Material. Online appendices are available at https://doi.org/10.1017/S0007123420000654.

Data Availability Statement. The data and analysis files that are necessary to replicate the findings in the article, and in the supplementary materials are available in Harvard Dataverse at: https://doi.org/10.7910/DVN/XMEDZD.

Acknowledgements. We are grateful to Alberto Palacios for helping to digitize and clean the data that are used in the article. We are also grateful for helpful advice from participants in the 13th Sound Workshop of Economic History in Gothenburg (2018), the seminar at 3rd Sound for Seniors at Helsinki (2018), the CES conference in Madrid (2019) and in seminars at Texas A\&M University and the University of Gothenburg (2018). Finally, we are grateful to the three anonymous referees and the editors of the BJPS for their comments and suggestions. Any remaining mistakes are ours.

Financial Support. Enflo and Cermeño acknowledge generous support from the Knut and Alice Wallenberg Foundation (KAW2014.0138) and Länsförsäkringars Forskningsfond (P2/17). Lindvall acknowledges generous financial support from Riksbankens Jubileumsfond (grant M14-0087:1) and the Swedish Research Council (grant 2016-00783).

\section{References}

Aghion P et al. (2019) Education and military rivalry. Journal of the European Economic Association 17(2), 376-412.

Andersson J and Berger T (2019) Elites and the expansion of education in 19th-century Sweden. The Economic History Review 72(3), 897-924.

Ansell B and Lindvall J (2013) The political origins of primary education systems. American Political Science Review 107(3), 505-522.

Ansell B and Lindvall J (2021) Inward Conquest. The Political Origins of Modern Public Services. New York: Cambridge University Press.

Baum-Snow N (2007) Did highways cause suburbanization? The Quarterly Journal of Economics 122(2), 775-805.

Baum-Snow N and Lutz BF (2011) School desegregation, school choice, and changes in residential location patterns by race. American Economic Review 101(7), 3019-3046.

Benavot A et al. (1991) Knowledge for the masses: world models and national curricula. American Sociological Review 56(1), 85-100.

Benavot A and Riddle P (1988) The expansion of primary education, 1870-1940: trends and issues. Sociology of Education 61(3), 191-210.

Bergenfeldt F (2014) Roads to market: transport and agricultural change - the case of southern Sweden, 1750-1850. Diss: Lund University, 2014.

Berger T and Enflo K (2017) Locomotives of local growth: the short- and long-term impact of railroads in Sweden. Journal of Urban Economics 98, 124-138.

Besley T and Persson T (2011) Pillars of Prosperity. Princeton: Princeton University Press.

Boije M and Prenzlau-Enander G (2003) “Postvägen.” Stockholms läns museum, Report 39.

Cermeño AL, Enflo K and Lindvall J (2021) Replication Data for Railroads and Reform: How Trains Strengthened the Nation State, https://doi.org/10.7910/DVN/XMEDZD, Harvard Dataverse, V1, UNF:6:jfPDUS1btXzdyFv6Im48bw== [fileUNF].

Clark AK (1998) The Redemptive Work: Railway and Nation in Ecuador, 1895-1930. Wilmington: Scholarly Resources.

Dunlavy CA (1994) Politics and Industrialization: Early Railroads in the United States and Prussia. Princeton: Princeton University Press.

Ekholm M and Lindvall K (2008) Skolinspektioner i tid och otid. Pedagogisk forskning i Sverige 13(1), 41-58.

Enflo K, Henning M and Schön L (2014) Swedish Regional GDP 1855-2000: estimations and general trends in the Swedish regional system. In Research in Economic History. Emerald Group Publishing Limited, pp. 47-89. https://doi.org/10.1108/ S0363-3268(2014)0000030000

Engerman SL and Sokoloff KL (1994) Factor Endowments: Institutions, and Differential Paths of Growth Among New World Economies: A View from Economic Historians of the United States. Working Paper 66, National Bureau of Economic Research. Available from http://www.nber.org/papers/h0066. 
Evertsson J (2012) Folkskoleinspektionen och moderniseringen av folkskolan i Sverige 1860-1910. Historisk Tidskrift 132(4), 2-29.

Finer SE (1997) The History of Government. Oxford: Oxford University Press, 3 Volumes.

Galor O, Moav O and Vollrath D (2009) Inequality in landownership, the emergence of human-capital-promoting institutions, and the great divergence. The Review of Economic Studies 76(1), 143-179.

Heckscher EF (1954) An Economic History of Sweden, vol. 95. Cambridge: Harvard University Press.

Hicks J (1969) A Theory of Economic History. Oxford: Oxford University Press.

Jägerskiöld S (1959) Från prästskola till enhetsskola. Stockholm: Almqvist \& Wiksell.

Jones K (1972) A History of the Mental Health Services. London: Routledge.

Lindert P (2004) Growing Public. Cambridge: Cambridge University Press.

Lipset SM and Rokkan S (1967) Party Systems and Voter Alignments. New York: Free Press.

Mann M (1993) The Sources of Social Power: Volume 2. The Rise of Classes and Nation States 1760-1914. Cambridge: Cambridge University Press.

McAdam D, Tarrow S and Tilly C (2001) Dynamics of Contention. Cambridge: Cambridge University Press.

Meyer JW, Ramirez FO and Soysal YN (1992) World expansion of mass education, 1870-1980. Sociology of Education 65, 128-149.

Morgan KJ (2002) Forging the frontiers between state, church, and family. Politics \& Society 30(1), 113-148.

Nall C (2018) The Road to Inequality: How the Federal Highway Program Polarized America and Undermined Cities. Cambridge: Cambridge University Press.

Nilsson T (2018) Mellan rådgivning och kontroll: Den statliga skolinspektionen som skolexempel 1861-1991. Stockholm: Södertörns högskola.

Nunn N and Puga D (2012) Ruggedness: the blessing of Bad geography in Africa. Review of Economics and Statistics 94(1), $20-36$.

Oredsson S (1969) Järnvägarna och det allmänna: Svensk järnvägspolitik fram till 1890. Lund: Bibliotheca historica Lundensis.

Schram A (1997) Railways and the Formation of the Italian State in the Nineteenth Century. Cambridge: Cambridge University Press.

Sjöberg A (1956) Järnvägarna i svenskt samhällsliv. In N.G Lindskog (ed.), Sveriges järnvägar hundra är. Stockholm: Kungliga Järnvägsstyrelsen, pp. 1-159.

Soifer H (2015) State Building in Latin America. Cambridge: Cambridge University Press.

Soysal YN and Strang D (1989) Construction of the first mass education systems in nineteenth century Europe. Sociology of Education 62(4), 277-288.

Statistiska Centralbyrån (1870) Folkundervisningen den 31 december 1868. Stockholm: SCB.

Tegborg L (1969) Folkskolans sekularisering 1895-1909. Stockholm: Föreningen för svensk undervisningshistoria.

Thelin B (1994) Skolinspektörer minns. Uppsala: Föreningen för svensk undervisningshistoria.

Weber E (1976) Peasants into Frenchmen. Palo Alto: Stanford University Press.

Cite this article: Cermeño AL, Enflo K, Lindvall J (2022). Railroads and Reform: How Trains Strengthened the Nation State. British Journal of Political Science 52, 715-735. https://doi.org/10.1017/S0007123420000654 